\title{
ACTITES, A NEW GENUS OF COMPOSITAE FROM AUSTRALIA
}

\author{
N. S. LANDER \\ (Received July 1975)
}

\section{ABSTRACT}

Lander, N.S. (National Herbarium of New South Wales, Royal Botanic Gardens, Sydney, Australia) 1976. Actites, A New Genus of Compositae for Australia. Telopea 1 (2): 129-135. -A new genus of Compositae, Actites, is distinguished from Embergeria and Sonchus. The new combination Actites megalocarpa (Hook.f.) N. Lander is made. A neotype for Sonchus asper var. littoralis Black and a lectotype for $S$. grandifolius Kirk are designated. The phytogeography of Actites and Embergeria is briefly discussed.

Boulos (1960, 1962, 1965 a \& b, 1967, 1968, 1972) has recognized four genera within Sonchus sens. lat.: Sonchus L., Babcockia Boulos, Taeckholmia Boulos and Embergeria Boulos. Sonchus is a cosmopolitan genus of some 54 species. Both the monotypic Babcockia and Taeckholmia, with seven species, are endemic to the Canary Islands. Two species have been included by Boulos in his Embergeria: E. grandiflora from New Zealand's Chatham Islands, and E. megalocarpa from Australia.

Boulos (1965 b) distinguished Embergeria from Sonchus on the seemingly inadequate basis of the coriaceous texture of the leaves and the large size of the cypsellas. Further, Boulos designated independent subgenera for each of the species of Embergeria separated by differences in the shape and size of the basal leaves and the tomentum of the peduncles, which hardly impress one as significant. Later, Pons and Boulos (1972) found that whilst the pollen of E. megalocarpa is indistinguishable from that of Sonchus subgen. Sonchus sect. Asperi Boulos, that of E. grandifolia is unique.

In his work to date, Boulos would appear to have overlooked variation in two very important characters, namely achene morphology and the nature of the pappus. Both species placed in Embergeria have singularly characteristic achenes, differing markedly from each other and from those of any Sonchus, as can be seen from the diagnostic key below. The pappus of Embergeria grandifolia consists entirely of simple, flexible bristles, whereas that of E. megalocephala is of the Sonchus type with both simple bristles and glochidial hairs. Boulos (1960) himself places considerable taxonomic weight on the presence or absence of glochidial pappus hairs amongst members of the Launaea-Sonchus group in the subtribe Crepidinae as did Stebbins (1953). Boulos attributes sufficient importance to this character to use it to distinguish Sonchus from related genera. Although descriptions of E. grandiflora published by Boulos (1965 b, 1972) report the pappus to be dimorphic, only simple bristles were seen in specimens of this species examined by myself.

These observations, together with the palynological findings of Pons \& Boulos (1972) mentioned above, provide the critical characters which prompt recognition of three separate genera.

\section{DIAGNOSTIC KEY TO SONCHUS, ACTITES AND EMBERGERIA}

1. Pappus with both simple bristles and glochidial hairs. Pollen tri- or tetra-colporate with 6 or 8 abporal, 6 or 8 paraporal and 2 polar lacunae surrounded by ridges surmounted with spines; polar lacunae with up to 29 spines. 
2. Achenes elliptical in outline, narrowed towards both ends, sometimes cylindrical; smooth or rough with wrinkles and/or tubercles; margins wingless or narrowly winged; each face with 1-4 prominent ribs which are never raised to form

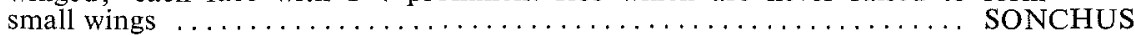

2.* Achenes flask-shaped in outline, constricted at apex, compressed, smooth; margins with broad, flat wings; each face with 3 prominent ribs each of which may be raised to form smaller secondary wings . . . . . . . . . . . ACTITES

1." Pappus with simple bristles only. Pollen tricolporate, uniformly spinous; abporal lacunae reduced, indistinct; paraporal lacunae absent. Achenes flask-shaped in outline, constricted at apex, somewhat swollen when mature; margins with broad, inflated wings; each face with 3-6 prominent ribs which are never raised to form small secondary wings $\ldots \ldots \ldots \ldots \ldots \ldots \ldots \ldots \ldots \ldots \ldots \ldots \ldots \ldots, \ldots \ldots$ EMBER GERIA

The present author feels it appropriate at this point to record his broad concurrence with the generic delimitations embodied in the continuing monographic treatment of Sonchus and its allies by Loutfy Boulos. An alternative treatment of this group would consider the entities Actites, Babcockia, Embergeria, Sonchus and Taeckholmia as subgenera of Sonchus sens. lat. It is the author's conviction that unless a comprehensive review of the subtribe Crepidinae is undertaken, no useful purpose would be served by abandoning Boulos's concepts at this stage.

\section{ACTITES}

\section{Actites $N$. Lander, gen. nov.}

Replaced Synonym: Embergeria subgen. Megalocarpa Boulos in $\mathrm{Hj}$. Eichler, Suppl. Black's Fl. South Australia: 333 (1965); Boulos, Bot. Not, 125 (4): 302 (1972).

Type Species: A. megalocarpa (Hook.f.) N. Lander.

Genus Sonchus L. differt cypselis alatis Embergeria differt pappo piloris glochidiatis.

Actites megalocarpa (Hook.f.) N. Lander, comb. nov.

Synonymy: Sonchus asper var. megalocarpus Hook.f., Fl. Tasmaniae 1 (3): 227 (1972). Sonchus megalocarpus (Hook.f.) Black, Fl. South Australia Ed. 1, 4: 661 (6.1929); Black in Trans. Roy. Soc. South Australia 53: 263 (12.1929); Ewart, Fl. Victoria: 1195 (1930); Black, Fl. South Australia Ed. 2, 4: 943 \& fig. 1259 (1956); Beadle, Evans \& Carolin, Handb. Vasc. Pl. Sydney Distr.: 396 (1963); Curtis, Stud. Fl. Tasmania 2: 390 (1963); Willis, Handb. Pl. Victoria 2: 773 (1973); Beadle, Evans \& Carolin, Fl. Sydney Region: 481 (1974). Embergeria megalocarpa (Hook.f.) Boulos in Eichler, Suppl. Black's Fl. South Australia: 333 (1965); Boulos in Bot. Not. 125 (4): 302, 309 \& 316-7 (1972). HoLOTYPE: "near the sea on the north shore of the Island [Tasmania]", Gumn $845(\mathrm{~K})$.

Sonchus asper var. littoralis Black, Naturalized Fl. South Australia: 104 (1909), nom. inval., non Kirk in Trans. New Zealand Inst. 26: 265 (1895). NeOTYPE (here designated): South Australia, Black NSW 135787,-(NSW). IsoTYPE to be sent to AD.

Since Black cited no specimens when he described his variety, it is appropriate to designate the above neotype. Although this specimen was received by Ernst Betche in January of 1913, it was probably collected much earlier; it is the only one of those examined labelled $S$. asper var. littoralis and the only one collected by Black himself.

Fleshy, perennial herbs, erect and up to $0.3 \mathrm{~m}$ high, with creeping rhizomes, forming large clumps. Stems branched, somewhat woody at their bases, otherwise herbaceous, with longitudinal furrows, glabrous. Leaves radical and cauline, alternate, deeply pinnatisect, lobed or entire, narrowly spathulate or lanceolate, $1 \cdot 5-17 \cdot 0(8 \cdot 5 \pm 0 \cdot 2) \dagger \mathrm{cm}$ long, $0 \cdot 5-4 \cdot 5(2 \cdot 1 \pm 0 \cdot 1) \mathrm{cm}$ wide, either tapering into

$\dagger$ Measurements are given in the form: range, followed by mean \pm standard error of the mean. (See also Table 1) 
narrow strap-like bases or sessile with cordate bases, coriaceous, glabrous; margins sinuate, irregularly prickly-dentate; apexes acute or obtuse, pointed. Capitula to $3 \mathrm{~cm}$ in diameter when opened, on stout, leafy, glabrous scapes up to $21 \mathrm{~cm}$ long; disc $1 \cdot 0-1 \cdot 5 \mathrm{~cm}$ in diameter. Involucral bracts $24-36$ on each capitulum, imbricate in 3-5 rows, narrowly triangular, $4-27 \mathrm{~mm}$ long, $1-5 \mathrm{~mm}$ wide, with a median line of up to 10 prominent spinous processes. Florets yellow, sometimes pale purple towards base, $10 \cdot 9-20 \cdot 0(15 \cdot 0 \pm 0.3) \mathrm{mm}$ long; ligules $5.5-9 \cdot 7(7 \cdot 0 \pm 0.2) \mathrm{mm}$ long, glabrous; floral tubes $5 \cdot 0-10.5(7.8 \pm 0.3) \mathrm{mm}$ long, sparsely pubescent immediately below ligule with multicellular, uniseriate, non-glandular hairs; anther tubes 1.9-3.8 $(2.9 \pm 0.1) \mathrm{mm}$ long; styles bilobed, each lobe light brown, 0.6-1.8 $(1.2 \pm 0.1) \mathrm{mm}$ long, densely barbellate with minute, unicellular barbs. Pappi persistent, $6 \cdot 5-14 \cdot 2(10 \cdot 9 \pm 0 \cdot 1) \mathrm{mm}$ long, consisting of many minutely barbellate bristles each tapering into a fine point and minutely barbellate glochidial hairs both in small tufts or free to their bases. Achenes cream-yellow, flask-shaped in outline, constricted at apex, $4 \cdot 3-8 \cdot 0(6 \cdot 2 \pm 0 \cdot 1) \mathrm{mm}$ long, $1 \cdot 3-3 \cdot 2(2 \cdot 2 \pm 0 \cdot 1) \mathrm{mm}$ wide, compressed, glabrous; margins with broad, flat wings; each face with 3 prominent ribs each of which may be raised to form smaller wings. Pollen tricolporate with 6 abporal, 6 paraporal and 2 polar lacunae surrounded by ridges surmounted by spines; polar lacunae with 2-9 spines. Flowering period from September to June. $2 n=36$, Pons \& Boulos (1972).

HaBiTAT: Only on coastal sand-dunes and cliffs.

Distribution: The southern and eastern coast of Australia from Toorbul in Queensland to Middleton Beach in Western Australia, as well as the southeastern coast of Tasmania.

Specimens Examined: QueEnsland: Moreton Bay District: Toorbul (as Durval), Leichhardt NSW 122475, 9.1843 (NSW); Point Lookout, North Stradbroke Island, Coveny' $2040,8.1969$ (NSW).

New South Wales: North Coast: Cape Byron, Betche NSW 122474, 4.1896 (NSW); Hat Head, Constable NSW 31822, 1.1953 (NSW); Crescent Head, Davis NSW 122480, 9.1939 (NSW); Newcastle, Cleland NSW 122473, 9.1912 (NSW). Central Coast: Wamberal, Cheel NSW 122472, 4.1911 (NSW); North Avoca Beach, S. of Terrigal, Garden NSW 122471, 12.1951 (NSW); between Palm Beach and Barrenjoey, Goode 271, 12.1954 (NSW); Avalon, Robin NSW 122476, 5.1949 (NSW); Narrabeen, Evans NSW 122464, 2.1926 (NSW); Collaroy Beach, Hamilton NSW 122470, 10.1916 (NSW); Dee Why, Prescott NSW 122461, 4.1938 (NSW); Manly, Fletcher NSW 122478-(NSW); Bondi, Blakely NSW 122469, 10.1913 (NSW); Rockdale Beach, Botany Bay, Camfield NSW 122462, 4.1893 (NSW); Lady Robinsons Beach, Betche NSW 122465, 1.1887 (NSW), Andrews NSW 122463, 5.1915 (NSW); Cronulla, Hamilton NSW 122466, 12.1916 (NSW); W. end of Windang Island, entrance to Lake lllawarra, Rodway NSW $522524,4.1938$ (NSW); Shoalhaven Head, 5 miles [8 km] SE. of Berry, Salasoo 3087, 1.1966 (NSW); Jerry Bailey Beach, mouth of Shoalhaven River, Rodway NSW 522523, 4.1936 (NSW). South Coast: Wheelers Point, Shoalhaven, Rodway NSW 522526, 2.1924 (NSW); Crookhaven Heads, Lucas \& Hamilton NSW 122467, 4.1917 (NSW); Bowen Island, Jervis Bay, Rodway NSW 122522, 10.1922 (NSW); Cudmirrah Beach, near the inlet to Swan Lake, Lander 348, 3.1974 (NSW); Lake Conjola, Henley NSW 122479, 4.1974 (NSW); Tabourie Lake, 6 miles $[9.6 \mathrm{~km}] \mathrm{SW}$. of Ulladulla, Salasoo 5059, 5.1973 (NSW); $5 \mathrm{~km} \mathrm{SW}$. of Pebbley Beach, $15 \mathrm{~km}$ NW. of Batemans Bay, Briggs 3118, 12.1969 (NSW); Broulee Beach, 5 miles [8 km] NE. of Moruya, Constable NSW 43108, 10.1957 (NSW), Mackiewicz NSW 122477, -.1965 (NSW); Tathra, 20 miles [32 km] S. of Bermagui, Constable 7378, 5.1967 (NSW); Tathra Tourist Beach Caravan Park, Seur 91, 3.1973 (NSW); South Coast, Stenhouse NSW 122468, 4.1954 (NSW).

VICTORIA: Tidal River, Wilsons Promontary, Dyce NSW 122481, 3.1965 (NSW); Sorrento, Mornington Peninsula, Willis 2.1963 (AD); E. side of mouth of Glenelg River at Nelson, Wilson 1177, 2.1975 (NSW).

Tasmania: Port Arthur, Maiden NSW 135785, 2.1906 (NSW); Sandy Beach (Long, Beach), Hobart, Rodway 5191, 12.1898 (NSW); Recherche Bay (as Richerche), Rodway 5194, 12.1901 (NSW); Tasmania, Archer NSW 135786,-(NSW).

South Australia: Port MacDonnell, Hunt 1890, 2.1964 (AD); Cape Northumberland, Wilson 1181, 2.1975 (NSW); S. of Cape Banks, Cleland 2.1945 (AD); Cape Buffon, Rivoli Bay, Cleland 2.1946 (AD); Bevilaqua Ford, Cleland 2.1947 (AD); Beachport, Ising 1.1925 (AD); between SW. Lake George and the sea, Wilson 1158, 11.1959 (AD); Goolwa Barrage, near Murray River mouth, Cleland 1.1951 (AD); Port Elliot, Encounter Bay, Cleland 1.1945 (AD); Port Elliot, Fleurieu Peninsula, Cleland 1.1945 (AD); between Victor Harbour and Port Elliot, Fleurieu Peninsula, Cleland 12.1954 (AD); Bluff (Rossetta Head) Encounter Bay, Fleurieu Peninsula, Cleland 1.1944 (AD); Encounter Bay, Cleland 1.1945 (AD); Fleurieu 
Peninsula, Cleland 3.1925 (AD); Wright Island, Encounter Bay, Fleurieu Peninsula, Cleland 2.1921 (AD); Henley Beach, Adelaide, Ising 11.1919 (AD); Vivonne Bay, S. Kangaroo Island, Cleland 12.1934 (AD); Corny Point, Lower Yorke Peninsula, Kraehenbuehl 863, 12.1962 (AD); Inneston National Park Yorke Peninsula, Symon 9763, 12.1974 (AD, NSW); Hanson Bay, SW. Kangaroo Island, Eichler 15335, 11.1958 (AD); Mouth of South West River, Kangaroo Island, Cleland 1.1940 (AD); Kangaroo Island, Cleland 2.1946 (AD); Flour Cask Bay, Kangaroo Island, Lothian 807, 1.1962 (AD); Red Banks, Eyre Peninsula, Adcock 2.1936 (AD); Wilsons Bluff, Great Australian Bight, Tate 2.1879 (AD); South Australia, Black NSW $135787,-$ (NSW).

Western Australia: Middleton Beach, Staer NSW 135788, 2.1911 (NSW).

The generic name is derived from Gk. aktites, a coast dweller.

\section{EMBERGERIA}

Embergeria Boulos in Eichler, Suppl. Black's Fl. South Australia: 332-3 (1965); Boulos, Bot. Not. 125 (4): 301-2 (1972).

TyPe Species: E. grandifolia (Kirk) Boulos.

Embergeria grandifolia (Kirk) Boulos in Eichler, loc. cit.; Boulos, Bot. Not. 125 (4): 301-2, $308 \&$ \& 316-7 (1972).

Synonymy: Sonchus grandifolius Kirk in Trans. \& Proc. New Zealand Inst. 26: 265-6 (5.1894); Kirk in J. Bot. 32: 184 (6.1894); Kirk, Stud. Fl. New Zealand: 362-3 (1899); Cockayne in Trans, \& Proc. New Zealand Inst. 34: 263 (1902); Cheeseman, Man. New Zealand Fl.: 388-9 (1906); Cockayne, New Zealand Pl. \& their Story: 140 (1919); Cockayne, Veg. New Zealand, Ed. 2: 333 \& fig. 95 (1928); Allan, Fl. New Zealand 1: 760 (1961).

Lectotype (here designated): Chatham Islands, J.D. Enys, 4.1891 (WELT 27965), excluding the loose capitulum and achenes in the packet affixed to the top left-hand corner of the mounting sheet and those glued to the specimen itself.

Lectoparatype: Cultivated at Christchurch, Adams \& Sons (WELT 27965) i.e. the capitula and achenes mentioned above.

From Kirk, Trans. \& Proc. New Zealand Inst. 26: 265-6 (1894) it is quite clear that the specimen sheet WELT 27965 actually comprises two collections designated as lectotype and lectoparatype above.

MisapPlied Names: Mueller, Veg. Chatham Islands: 31 (1865) referred a specimen of this species to Sonchus oleraceus $\mathrm{L}$.

Fleshy perennial herbs, erect and up to $1.5 \mathrm{~m}$ high, with creeping rhizomes, forming large clumps. Stems branched, herbaceous with longitudinal furrows, for the most part glabrous but often with patches of dense white tomentum, particularly in the leaf axils. Radical leaves alternate, deeply pinnatisect with 4-6 broad segments on each side often overlapping, coriaceous, ovate, $12 \cdot 5-34 \cdot 0$ $(24.6 \pm 2 \cdot 1) \mathrm{cm}$ long, $10 \cdot 0-19 \cdot 5(16 \cdot 4 \pm 1 \cdot 2) \mathrm{cm}$ wide, scabrid above; margins sinuate, irregularly prickly-dentate; apexes acute, pointed; petioles stout, c. $1 \mathrm{~cm}$ in diameter, to $25 \mathrm{~cm}$ long, dilated at bases but not sheathing. Cauline leaves alternate, entire, narrowly to broadly ovate, $5 \cdot 0-21 \cdot 0(9 \cdot 8 \pm 1 \cdot 3) \mathrm{cm}$ long, $2 \cdot 0-7 \cdot 0$ $(4.3 \pm 0.5) \mathrm{cm}$ wide, sessile with broad bases, scabrid above; margins sinuate, irregularly prickly dentate; apexes acute, pointed. Capitula to $4 \mathrm{~cm}$ in diameter when opened, on stout, leafy, densely white-tomentose scapes to $3.5 \mathrm{~cm}$ long; disc $1.0-1.7 \mathrm{~cm}$ in diameter. Involucral bracts c. 24-30 on each capitulum, imbricate in 3-4 rows, narrowly triangular, 5-21 $\mathrm{mm}$ long, 2-6 $\mathrm{mm}$ wide, with a median line of up to 10 prominent spinous processes. Florets yellow, tinged at the apices with faint salmon color or purple, $12 \cdot 1-20 \cdot 0(15.5 \pm 0.5) \mathrm{mm}$ long; ligules $6 \cdot 0-9 \cdot 4$ $(6.9 \pm 0.3) \mathrm{mm}$ long; fioral tubes $8 \cdot 6-12 \cdot 0(10 \cdot 5 \pm 0.3) \mathrm{mm}$ long, densely pubescent immediately below ligule for c. $\frac{1}{3}$ of their length with multicellular, uniseriate, nonglandular hairs; anther tubes $2 \cdot 5-3 \cdot 8(3 \cdot 3 \pm 0 \cdot 1) \mathrm{mm}$ long; styles bilobed, each lobe black, $1 \cdot 0-2 \cdot 6(1 \cdot 5 \pm 0 \cdot 1) \mathrm{mm}$ long; densely barbellate with minute unicellular barbs. Pappi persistent, $8 \cdot 0-14 \cdot 0(12 \cdot 0 \pm 0.5) \mathrm{mm}$ long, consisting of many 
minutely barbellate bristles either free to their bases or united in small bundles, each tapering into a fine point. Achenes cream-yellow, flask-shaped in outline, constricted at apex, $5 \cdot 7-10 \cdot 1(8 \cdot 5 \pm 0 \cdot 5) \mathrm{mm}$ long, $3 \cdot 0-5 \cdot 3(4 \cdot 1 \pm 0 \cdot 3) \mathrm{mm}$ wide, swollen when mature, glabrous; margins with broad, inflated wings; each face with 3-6 ribs none of which is raised into a distinct wing. Pollen tricolporate, uniformly spinous; abporal lacunae reduced, indistinct, paraporal lacunae absent. Flowering period from December to April. $2 n=36$, Stebbins et al. (1953).

HaBiTAT: Only on coastal sand-dunes and cliffs.

Distribution: Restricted to New Zealand's Chatham Islands.

Specimens Examined: NEW ZEALAND: Chatham Islands: Lectotype, see above; Petrie-(WELT 27960); Travers-(WELT 27964 in part, 33940, 33968); Red Bluff, Chatham Island, Oliver 12.1909 (WELT 9581); Flowerpot, Pitt Island, Hamlin 671, 1.1957 (WELT 3311, NSW); Cultivated at Christchurch, SYNTYPE, see above; "Cultivated in my garden at Epsom, Auckland", Petrie (WELT 27961-3, 27966); Locality unknown, collector unknown, ex Herb. Kirk 2.1894 (WELT 2947-50).

The conclusion that Actites and Embergeria evolved from Sonchus is inescapable. Cytological and morphological data gathered by Boulos (1967) led him to suggest the subgenus Sonchus as the most probable ancestor of Embergeria sensu Boulos. The palynological findings of Pons \& Boulos (1972) and the further cytological investigations of Roux \& Boulos (1972) confirm this and point strongly to the section Asperi as the possible ancestor.

In large degree, Sonchus is indigenous to Europe, Asia and northern Africa. The most primitive subgenus, Origosonchus Boulos, is found only in tropical West Africa. Subgenus Dendrosonchus Webb ex Schultz Bip. is composed of species adapted to island life (see Carlquist, 1965, ch. 8) with the majority restricted to Madeira and the Canary and Cape Verde Islands. The most advanced subgenus, Sonchus, is variable and exceedingly widespread; several of its species are cosmopolitan weeds.

Significantly, both S. hydrophilus Boulos, endemic to Australia, New Guinea and New Zealand, and $S$. littoralis (Kirk) Allan, endemic to New Zealand only, are members of the section Asperi in the subgenus Sonchus. Other species in the Asperi are: S. mauritanicus Boiss. et Reut., from Mauritius; S. gigas Boulos ex Humbert, from tropical and subtropical Africa and Malagasy; S. macrocarpus Boulos et Jeffrey, from Egypt; $S$. asper (L.) Hill, of Mediterranean origin but now a cosmopolitan weed.

Compositae, which produce abundant, easily recognizable pollen, first appear in the fossil record anywhere in the world in the uppermost Oligocene (Germaraad et al., 1969; Becker, 1969; Muller, 1970; Raven \& Axelrod, 1974) with the tribe Cichorieae appearing in the upper Miocene; this timing also holds true for New Zealand (Couper, 1960). The fossil record shows new plants continually appearing during the Tertiary, apparently coming from several different directions (Darlington, 1965). For many plant groups that migrated into Australasia, a late Pliocene or more recent date of arrival in the South seems likely (Raven, 1972).

Wardle (1963) distinguishes a small but very distinct endemic element in the Chatham Islands flora consisting of four species including Embergeria grandifolia. According to Wardle this element implies survival on the Chatham Islands during the Pleistocene glaciation and indicates that the climatic fluctuations of that epoch had much less effect on the insular flora than on that of the New Zealand mainland.

It seems reasonable to conclude therefore that during the late Pliocene the subgenus Sonchus migrated to Australia and New Zealand where subsequently the genera Actites and Embergeria had their respective origins. 


\section{ACKNOWLEDGEMENTS}

I wish to thank Miss Heidi Fallding for her assistance in this study; also the Director of The National Museum of New Zealand, Wellington, and the Keeper of The State Herbarium of South Australia for making specimens available to me.

\section{LITERATURE CITED}

Becker, H.F., 1969-Fossil plants of the Tertiary Beaverhead Basin in southwestern Montana. Paläeontographica Abt. B. Paläophytol. 127: 1-142.

Boulos, L., 1959-Cytotaxonomic studies in the genus Sonchus. 1. S. gigas Boulos nov. sp., a new tetraploid Egyptian species. Bot. Not. 112: 363-366.

Boulos, L., 1960-Cytotaxonomic studies in the genus Sonchus. 2. The genus Sonchus, a general systematic treatment. Bot. Not. 113: 400-420.

Boulos, L., 1962-Cytotaxonomic studies in the genus Sonchus. 4. The generic status of some species earlier treated as Sonchus. Bot. Not. 115: 58-60.

Boulos, L., 1965 a-Babcockia, un nouveau genre de Composées des îles Canaries. Bull. Jard. Bot. État 35: 63-66.

Boulos, L., 1965 b-Sonchus and Embergeria. In Hj. Eichler, Supplement to Black's Flora of South Australia: 330-333.

Boulos, L., 1967-Taeckholmia, a new genus of Compositae from Canary Islands. Bot. Not. 120: 95-108.

Boulos, L., 1968-The genus Sonchus and allied genera in the Canary Islands. Cuadernos Bot. 3: 19-26.

Boulos, L., 1972-Révision systématique du genre Sonchus L. s.l. I. Introduction et classification. Bot. Not. 125: 287-305.

Carlquist, S., 1965-Island Life. American Museum of Natural History, New York.

Couper, R.A., 1960-New Zealand Mesozoic and Cainozoic plant micro-fossils. New Zealand Geol. Surv. Paleont. Bull. 32.

Darlington, P.J., Jr., 1965-Biogeography of the southern end of the world. Harvard University Press, Cambridge, Massachusetts.

Germeraad, J.H., Hopping, C.A. \& Muller, J., 1968-Palynology of Tertiary sediments from tropical areas. Rev. Palaeobot. Palynol. 6: 189-348.

Muller, J., 1970-Palynological evidence on early differentiation of angiosperms. Biol. Rev. Cambridge Philos. Soc. 45: 417-50.

Pons, A. and Boulos, L., 1972-Révision systématique du genre Sonchus L. s.1. III. Étude palynologique. Bot. Not. 125: 310-319.

Raven, P.H., 1972-Evolution of subalpine and alpine plant groups in New Zealand. New Zealand J. Bot. 11: 177-200.

Raven, P.H. \& Axelrod, D.I., 1974-Angiosperm biogeography and past continental movements. Ann. Missouri Bot. Gard. 61: 539-673.

Roux, J. and Boulos, L., 1972-Révision systématique du genre Sonchus L. s.1. II. Étude caryologique. Bot. Not. 125: 306-309.

Stebbins, G.L., (1953)-A new classification of the tribe Cichorieae, family Compositae. Madroño $12(2)$ : 65-81.

Wardle, P., 1963 -Evolution and distribution of the New Zealand fiora, as affected by Quaternary climates. New Zealand J. Bot. 1: 3-17. 
Table 1

Actites megalocarpa

Leaf length $(\mathrm{cm})$

Leaf width $(\mathrm{cm})$

Ligule length (mm)

Floral tube length $(\mathrm{mm})$

Floret length $(\mathrm{mm})$

Anther length (mm)

Stigmatic lobe length (mm)

Cypsella length (mm)

Cypsella width $(\mathrm{mm})$
Pappus length ( $\mathrm{mm})$

$\begin{array}{rcrc}\overline{\mathrm{X}} \pm \text { S.E. } & \text { Range } & \mathrm{n} & \mathrm{N} \\ 8 \cdot 5 \pm 0 \cdot 2 & 1 \cdot 5-17 \cdot 0 & 169 & 60 \\ 2 \cdot 1 \pm 0 \cdot 1 & 0 \cdot 5-4 \cdot 5 & 169 & 60 \\ 7 \cdot 0 \pm 0 \cdot 2 & 5 \cdot 5-9 \cdot 7 & 48 & 16 \\ 7 \cdot 8 \pm 0 \cdot 3 & 5 \cdot 0-10 \cdot 5 & 48 & 16 \\ 15 \cdot 0 \pm 0 \cdot 3 & 10 \cdot 9-20 \cdot 0 & 48 & 16 \\ 2 \cdot 9 \pm 0 \cdot 1 & 1 \cdot 9-3 \cdot 8 & 48 & 16 \\ 1 \cdot 2 \pm 0 \cdot 1 & 0 \cdot 6-1 \cdot 8 & 48 & 16 \\ 6 \cdot 2 \pm 0 \cdot 1 & 4 \cdot 3-8 \cdot 0 & 138 & 46 \\ 2 \cdot 2 \pm 0 \cdot 1 & 1 \cdot 3-3 \cdot 2 & 138 & 46 \\ 10 \cdot 9 \pm 0 \cdot 1 & 6 \cdot 5-14 \cdot 2 & 138 & 46\end{array}$

\section{Embergeria grandifolia}

Radical leaf length $(\mathrm{cm})$

Radical leaf width $(\mathrm{cm})$

$\begin{array}{rcrr}24 \cdot 5 \pm 2 \cdot 1 & 12 \cdot 5-34 \cdot 0 & 8 & 6 \\ 16 \cdot 4 \pm 1 \cdot 2 & 10 \cdot 0-19 \cdot 5 & 8 & 6 \\ 9 \cdot 8 \pm 1 \cdot 3 & 5 \cdot 0-21 \cdot 0 & 15 & 11 \\ 4 \cdot 3 \pm 0 \cdot 5 & 2 \cdot 0-7 \cdot 0 & 15 & 11 \\ 7 \cdot 3 \pm 0 \cdot 2 & 6 \cdot 3-8 \cdot 5 & 20 & 10 \\ 10 \cdot 5 \pm 0 \cdot 3 & 8 \cdot 6-12 \cdot 0 & 20 & 10 \\ 17 \cdot 9 \pm 0 \cdot 4 & 15 \cdot 3-20 \cdot 4 & 20 & 10 \\ 3 \cdot 3 \pm 0 \cdot 1 & 2 \cdot 5-3 \cdot 8 & 20 & 10 \\ 1 \cdot 5 \pm 0 \cdot 1 & 1 \cdot 0-2 \cdot 6 & 16 & 8 \\ 8 \cdot 5 \pm 0 \cdot 5 & 5 \cdot 7-10 \cdot 1 & 10 & 5 \\ 4 \cdot 1 \pm 0 \cdot 3 & 3 \cdot 0-5 \cdot 3 & 10 & 5 \\ 12 \cdot 0 \pm 0 \cdot 5 & 8 \cdot 0-14 \cdot 0 & 10 & 5\end{array}$

Cauline leaf width $(\mathrm{cm})$

Ligule length (mm)

Floral tube length (mm)

Floret length $(\mathrm{mm})$

Anther length (mm)

Stigmatic lobe length (mm)

Cypsella length (mm)

Cypsella width (mm)

Pappus length (mm)

$$
\begin{aligned}
\overline{\mathrm{x}} \pm \mathrm{S} . \mathrm{E} . & =\text { mean } \pm \text { standard error of the mean } \\
\mathrm{n} & =\text { number of measurements and } \\
\mathrm{N} & =\text { number of specimens. }
\end{aligned}
$$

